\title{
Synergistic Efficacy of Tissue Extracts of Alstonia boonei and Vitex grandifolia against Some Common Bacteria Pathogens
}

\author{
Justice Oyindeinyefa Epidi", Esther Benafegha Enaregha \\ Department of Biology, Isaac Jasper Boro College of Education, Sagbama, Bayelsa State, Nigeria
}

*Corresponding Author: Justice Oyindeinyefa Epidi, Department of Biology, Isaac Jasper Boro College of Education, Sagbama, Bayelsa State, Nigeria

\begin{abstract}
This study evaluated the Synergistic efficacy of tissue extracts of Alstonia boonei and Vitex grandifolia against some common bacteria pathogens. Both plants were obtained from freshwater swamp in Wilberforce Island, Nigeria. Water, ethanol, methanol and hexane were used to extract the dried plant materials in a ratio of 1:1. Agar well diffusion technique was employed for the sensitivity testing. The results revealed that ethanolic extracts had superior zone of inhibition on the overall. The highest zone of inhibition for synergistic potency of the ethanolic extracts were 13.00mm (Bacillus sp) in root + leaf, $15.00 \mathrm{~mm}(\mathrm{~S}$. aureus) in root + leaf, $13.00 \mathrm{~mm}$ (P. aeruginosa) in stem + leaf, $14.00 \mathrm{~mm}$ (Proteus sp) in stem + leaf, and $15.00 \mathrm{~mm}$ (Salmonella sp) in root + leaf. There was significant variations $(P<0.05)$ in the zone of inhibition that was achieved for each of the bacterium under study and plant parts. The synergistic results of two or more parts of the plant combinations were superior as compared to the individual tissue extracts. The antimicrobial activities of the synergy of Alstonia boonei and Vitex grandifolia tissues suggests that it can be used as broad spectrum antibiotics.
\end{abstract}

Keywords: Antibacterial, Alstonia boonei, Medicinal plants, Microorganisms, Vitex grandifolia

\section{INTRODUCTION}

Despite the advancement made in the field of pharmaceutical microbiology and chemistry there is still a problem of antibiotics resistance. This is a major source of concern globally probably due to the resistance to emerging and re-emerging microbial infection. To this effect, studies have been carried out on potential alternative to this antibiotics and plant extracts have emerged as credible candidate. Plants with medicinal purpose has been widely used in the treatment of various types of diseases.

Authors have variously reported that medicinal plant are plants that one or more parts (including leaves, flower, fruit, latex, stem-bark, root etc) have medicinal potentials (Izah et al., 2018a-d; Izah and Aseibai, 2018; Izah, 2018; Kigigha et al., 2018, 2016, 2015). Medicinal plant is nature's gift to humanity and have been widely used. Authors have variously reported that approximately $75-80 \%$ of world population still rely on the use of herbs for the treatment and management of some ailments (Gahlaut and Chhillar, 2013; Fatima et al., 2011; Minochecherhomji and Vyas, 2014; Epidi et al., 2016a,b; Kigigha et al., 2015, 2016). Most of the individuals that rely on traditional medicine practitioners for the management of diseases reside in the rural area in many regions of developing nations. Amole and Ilori (2010) attributed this to economic factors and unavailability of modern drugs in the rural areas. A significant number of world population reside in rural areas in many developing nations. As such medicinal plants form the basis of primary health care services for many people in the region.

Many medicinal plant is a rich source of antimicrobial agents. This is probably due to the bioactive ingredients they contain. As such traditional medicine are source of potentially useful compounds for the development of phytotherapeutic agents with antimicrobial potentials. Plants with antimicrobial potentials have enormous therapeutic likelihood for the treatment of diseases caused by microbes. Several plants have been reported to have antimicrobial potentials in literature. But information about the synergy of one or more plant parts or species is often scanty in literature.

For instance, plant such as Vitex grandifolia and Alstonia boonei have been reported to contain antibacterial activity (Epidi et al., 2016a,b). Alstonia boonei which is popularly known as Alstonia, 
stoolwood etc belongs to Apocynaceae family, and are used by traditional health practitioners in rural areas to manage several disease conditions (Epidi et al., 2016a). Alstonia boonei is a facultative plant having estimated occurrence probability of $33-67 \%$ in both wetland and non-wetland areas (Epidi et al., 2016a). Furthermore, Vitex grandifolia is also known as Black plum, Chocolate and berry tree (Azokou et al., 2013). The plant is also found in the tropical rain forest of the Niger Delta but predominantly found in the non-wetland region of Nigeria. Thus, it is a facultative upland plant found in both wetland and non-wetland areas. Typically the genus Vitex are known to have pharmacological potentials (Owolabi et al., 2010; Rani and Sharma, 2013)probably due to the presence of essential oils, flavonoids, iridoids, glycosides, diterpenoides and ligans they contain (Rani and Sharma, 2013). Even in the traditional setting they have been applied for the treatment of several diseases (Ganapaty and Vidyadhar, 2005) and controlling pests such as Tribolium castaneum(Epidi and Odili, 2009).

The synergy of the parts of Vitex grandifolia has been reported in literature using different solvents for extraction (Epidi et al., 2016b). Furthermore, Epidi et al. (2018a) also reported the antibacterial activities of different parts of Alstonia boonei. Hence the present study aimed at assessing the synergistic effectiveness of the different parts of both Vitex grandifolia and Alstonia boonei.

\section{MATERIALS AND METHODS}

\subsection{Source of Plant Material}

The Vitex grandifolia and Alstonia boonei were obtained from the freshwater swamp in Wilberforce Island. For each of the plants, the different tissues (leaf, root and stem) were obtained. The Alstonia boonei was identified based on the morphological characteristics presented by Adomi and Umukoro (2010), Nyananyo (2006), Onwusoye and Uwakwe (2014), Akinloye et al. (2013), Momoh et al. (2014). While the Vitex grandifolia was identified based on the information presented by Owolabi $e t$ al. (2010), Lemmens (2008) and Azokou et al. (2013).

\subsection{Samples Collection, Preparation and Extraction}

The plant tissues were allowed to air dry in the laboratory. The different tissues of both plants were macerated using electronic blender. The various parts of Vitex grandifolia were combined with that of Alstonia booneiin a 1:1 ratio. For instance, the root of Vitex grandifolia were combined with the root of Alstonia boonei, the stem-bark of Vitex grandifolia were combined with the stem-bark of Alstonia boonei and the leaves of Vitex grandifolia were combined with the leaves of Alstonia boonei. A total of $40 \mathrm{~g}$ of the powdered plant (viz 20g from Vitex grandifolia part and $20 \mathrm{~g}$ from Alstonia boonei parts) were soaked in $100 \mathrm{ml}$ of each solvent i.e water, hexane, ethanol and methanol for 48 hours. Thereafter, the samples were filtered using muslin cloth. The extracts were further filtered using Whateman \#1 filter paper. The filtrates were then concentrated using rotary evaporator.This process was carried out in triplicate.

\subsection{Source and Preparation of Organisms}

The bacteria isolates used for the study including Staphylococcus aureus, Pseudomonas aeruginosa, Bacillus, Salmonella and Proteus species were obtained from the stock culture in the Medical Microbiology and Parasitology Department, College of Health Sciences, Niger Delta University, Nigeria. The purity of the isolates were determined following standard biochemical procedure including gram reaction, motility, catalase, coagulase, oxidase, citrate, urease and indole on the organisms using the scheme of Benson (2002), Cheesbrough (2004). Furthermore, the Staphylococcus aureus was streaked in Mannitol salt Agar which showed yellow pigmentation. Klingon Iron Agar was also used for the confirmatory test of Pseudomonas aeruginosa, Salmonella and Proteus species.

\subsection{Antimicrobial Screening of the Extract}

Agar diffusion technique previously described by Opoku and Akoto (2015), Ere et al. (2014) and has been applied by Izah and Aseibai (2018), Izah et al. (2018b-d), Kigigha et al. (2018, 2016, 2015) were employed. Approximately $2 \mathrm{ml}$ of 24 hours culture were spread on the prepared Mueller Hilton agar. Then after, four wells of $6.0 \mathrm{~mm}$ diameter were made on the agar plates using sterile cock borer. $2 \mathrm{ml}$ of the concentrated aqueous, ethanolic, methanolic and hexane extract were dispensed into each of the wells using micropipette. The plates were properly labeled and then incubated. The plates were 
incubated at $37^{\circ} \mathrm{C}$ for 24 hours under aerobic conditions. Thereafter, the zone of inhibition was measured using a meter rule.

\subsection{Statistical Analysis}

SPSS software version 16 was used to carry out the statistical analysis. The data were expressed as Mean \pm standard error. Significant difference was determined at $\alpha=0.05$ using one-way analysis of variance. Where significant variations exist, Duncan Multiple Range Test was used to compare the means.

\section{RESULTS AND DISCUSSION}

The Zone of inhibition for the various extracts (i.e. ethanol, methanol, hexane and water) of $V$. grandifolia + A. boonei is presented in Table 1 . The zone of inhibition of the ethanolic extracts ranged from $11.00-13.00 \mathrm{~mm}$ (root), $9.67-13.00 \mathrm{~mm}$ (stem), $11.00-13.00 \mathrm{~mm}$ (leaf), $10.67-13.00$ (root + stem), $12.00-15.00 \mathrm{~mm}$ (root + leaf), $10.00-14.00 \mathrm{~mm}$ (stem + leaf) and $10.00-13.00 \mathrm{~mm}$ (stem + leaf + root $)$. Basically, there were significant differences $(\mathrm{P}<0.05)$ among the different microorganisms across the various plant tissues.

The synergistic potency of the ethanol extracts was highest at root + leaf with zone of inhibition of $13.00 \mathrm{~mm}$ (Bacillus sp), root + leaf with zone of inhibition of $15 \mathrm{~mm}(S$. aureus), stem + leaf with zone of inhibition of $13 \mathrm{~mm}$ (P. aeruginosa), stem + leaf with zone of inhibition of $14 \mathrm{~mm}$ (Proteus $\mathrm{sp}$ ) and root + leaf with zone of inhibition of $15 \mathrm{~mm}$ (Salmonella sp). There were significant variations $(\mathrm{P}<0.05)$ in the highest zone of inhibition that was achieved for each of the bacterium under study.

The zone of inhibition of the methanolic extracts ranged from $11.00-13.67 \mathrm{~mm}$ (root), $10.00-13.00$ $\mathrm{mm}$ (stem), $9.00-13.33 \mathrm{~mm}$ (leaf), $10.00-12.33$ (root + stem), $11.00-14.00 \mathrm{~mm}$ (root + leaf), $11.00-13.00 \mathrm{~mm}$ (stem + leaf) and $9.00-12.33 \mathrm{~mm}$ (stem + leaf + root). Fundamentally, there were significant differences $(\mathrm{P}<0.05)$ among the different microorganisms across the various plant tissues.

The synergistic result of the methanolic extracts was highest at root + leaf with zone of inhibition of $14.00 \mathrm{~mm}$ (Bacillus sp), root + leaf with zone of inhibition of $13 \mathrm{~mm}$ (S. aureus), stem + leaf with zone of inhibition of $13.33 \mathrm{~mm}$ ( $P$. aeruginosa), root + leaf and root with zone of inhibition of $13 \mathrm{~mm}$ (Proteus sp) and stem with zone of inhibition of $13 \mathrm{~mm}$ (Salmonella sp). Statistically, there were significant variations $(\mathrm{P}<0.05)$ in the highest zone of inhibition that was achieved in each of the bacterium under study.

The zone of inhibition of the different bacteria from the hexane extracts of the different plant tissues ranged from $10.67-13.00 \mathrm{~mm}$ (root), $10.00-13.00 \mathrm{~mm}$ (stem), $10.00-12.33 \mathrm{~mm}$ (leaf), $11.67-$ 13.00mm apart from Bacillus sp that was resistant (root + stem), $12.33-14.33 \mathrm{~mm}$ (root + leaf), $11-$ $13.00 \mathrm{~mm}$ (stem + leaf) and $10.00-13.67 \mathrm{~mm}$ apart $P$. aeruginosa which was resistant (stem+ root+ leaf). However, there were significant differences $(\mathrm{P}<0.05)$ among most of the bacteria in each of the plant tissues and its combinations.

The synergistic potency results of the different plant tissues showed that the highest zones of inhibition of $13.67 \mathrm{~mm}$ (Salmonella sp), 12.33 mm (Bacillus sp), 14.33mm (P. aeruginosa), $13.00 \mathrm{~mm}$ (Proteus sp) and $14.00 \mathrm{~mm}$ (S. aureus) were obtained from root + leaf + stem, root + leaf and root, leaf + root, root+ stem and stem + leaf + root and leaf + root respectively. Statistically, significant variations $(\mathrm{P}<0.05)$ exist in the highest zone of inhibition that was achieved in each of the bacterium under study.

The zone of inhibition of the different bacteria from the aqueous water extracts of the different plant tissues ranged from $9.67-11.67 \mathrm{~mm}$ (root), $9.33-11.00 \mathrm{~mm}$ (stem), $8.00-10.33 \mathrm{~mm}$ (leaf), $9.00-$ $11.00 \mathrm{~mm}$ (root + stem), $10.00-12.33 \mathrm{~mm}$ (root + leaf), $10.67-14.00 \mathrm{~mm}$ (stem and leaf) and 9.33 $11.67 \mathrm{~mm}$ (stem+ root+ leaf). However, zone of inhibition of extracts of root for $S$. aureus, leaf for Proteus sp, root + stem for Bacillus sp, leaf + stem for Proteus and Bacillus sp, stem+ root+ leaf for $P$. aeruginosa were $0.00 \mathrm{~mm}$. There were significant differences $(\mathrm{P}<0.05)$ among most of the bacteria in each of the plant tissues and its combinations. 
Synergistic Efficacy of Tissue Extracts of Alstonia boonei and Vitex grandifolia against Some Common Bacteria Pathogens

Table1. Zone of inhibition for the various extracts of $V$. grandifolia $+A$. boonei

\begin{tabular}{|c|c|c|c|c|c|}
\hline $\begin{array}{l}\text { Plant } \\
\text { tissues }\end{array}$ & Microorganisms & Ethanol & Methanol & Hexane & Water \\
\hline \multirow[t]{5}{*}{ Root } & Bacillus sp & $11.67 \pm 0.33 \mathrm{abcd}$ & $11.33 \pm 0.33$ bcde & $12.33 \pm 0.33$ defgh & $9.67 \pm 0.33 \mathrm{cde}$ \\
\hline & S. aureus & $12.33 \pm 1.20 \mathrm{cde}$ & $10.33 \pm 0.33 \mathrm{abc}$ & $10.67 \pm 0.33 \mathrm{bcd}$ & $0.00 \pm 0.00 \mathrm{a}$ \\
\hline & P. aeruginosa & $12.33 \pm 0.33 \mathrm{cde}$ & $13.67 \pm 0.33 \mathrm{gh}$ & $11.00 \pm 0.58 \mathrm{bcde}$ & $9.67 \pm 0.33 \mathrm{cde}$ \\
\hline & Proteus sp & $13.00 \pm 0.58 \mathrm{def}$ & $13.00 \pm 0.58 \mathrm{efgh}$ & $13.00 \pm 0.58$ fghi & $11.33 \pm 0.33 \mathrm{fgh}$ \\
\hline & Salmonella $\mathrm{sp}$ & $11.00 \pm 0.58 \mathrm{abcd}$ & $11.00 \pm 0.58 \mathrm{bcd}$ & $12.67 \pm 0.33$ efghi & $11.67 \pm 0.33 \mathrm{gh}$ \\
\hline \multirow[t]{5}{*}{ Stem } & Bacillus sp & $11.00 \pm 0.58 \mathrm{abcd}$ & $11.00 \pm 0.58 \mathrm{bcd}$ & $11.00 \pm 0.58 \mathrm{bcde}$ & $11.00 \pm 0.58 \mathrm{efgh}$ \\
\hline & S. aureus & $10.00 \pm 0.58 \mathrm{ab}$ & $10.00 \pm 0.58 \mathrm{ab}$ & $10.00 \pm 0.58 \mathrm{~b}$ & $10.00 \pm 0.58 \mathrm{cde}$ \\
\hline & P. aeruginosa & $9.67 \pm 0.33 a$ & $10.33 \pm 0.33 a b c$ & $10.33 \pm 0.33 b c$ & $10.33 \pm 0.33$ cdefg \\
\hline & Proteus sp & $11.00 \pm 0.58 \mathrm{abcd}$ & $11.00 \pm 0.58 \mathrm{bcd}$ & $11.00 \pm 0.58 \mathrm{bcde}$ & $9.33 \pm 0.33 \mathrm{bcd}$ \\
\hline & Salmonella $\mathrm{sp}$ & $13.00 \pm 0.58 \mathrm{def}$ & $13.00 \pm 0.58 \mathrm{efgh}$ & $13.00 \pm 0.58$ fghi & $10.33 \pm 0.33 \mathrm{cdefg}$ \\
\hline \multirow[t]{5}{*}{ Leaf } & Bacillus sp & $11.00 \pm 0.58 \mathrm{abcd}$ & $11.00 \pm 0.58 \mathrm{bcd}$ & $10.00 \pm 0.58 \mathrm{~b}$ & $8.00 \pm 0.58 b$ \\
\hline & S. aureus & $12.67 \pm 0.88 \mathrm{cde}$ & $11.33 \pm 0.33$ bcde & $11.33 \pm 0.33$ bcdef & $10.00 \pm 0.00 \mathrm{cdef}$ \\
\hline & P. aeruginosa & $11.00 \pm 0.58 \mathrm{abcd}$ & $13.00 \pm 0.88 \mathrm{efgh}$ & $12.33 \pm 0.33$ defgh & $10.33 \pm 0.33 \mathrm{cdefg}$ \\
\hline & Proteus $\mathrm{sp}$ & $11.00 \pm 0.58 \mathrm{abcd}$ & $11.00 \pm 0.58 \mathrm{bcd}$ & $11.00 \pm 0.58 \mathrm{bcde}$ & $0.00 \pm 0.00 \mathrm{a}$ \\
\hline & Salmonella $\mathrm{sp}$ & $13.00 \pm 0.58 \mathrm{def}$ & $9.00 \pm 0.58 \mathrm{a}$ & $10.00 \pm 0.58 b$ & $9.00 \pm 0.58 \mathrm{bc}$ \\
\hline \multirow{5}{*}{$\begin{array}{l}\text { Root }+ \\
\text { stem }\end{array}$} & Bacillus sp & $12.00 \pm 0.58 \mathrm{bcde}$ & $10.00 \pm 0.58 \mathrm{ab}$ & $0.00 \pm 0.00 \mathrm{a}$ & $0.00 \pm 0.00 \mathrm{a}$ \\
\hline & S. aureus & $13.00 \pm 0.58 \mathrm{def}$ & $10.67 \pm 0.33 \mathrm{abcd}$ & $13.00 \pm 0.58$ fghi & $10.67 \pm 0.33 \mathrm{defg}$ \\
\hline & P. aeruginosa & $10.67 \pm 0.33 \mathrm{abc}$ & $11.67 \pm 0.88 \mathrm{bcde}$ & $11.67 \pm 0.88 \mathrm{bcdef}$ & $9.00 \pm 0.58 \mathrm{bc}$ \\
\hline & Proteus sp & $11.67 \pm 0.88 \mathrm{abcd}$ & $10.67 \pm 0.88 \mathrm{abcd}$ & $13.00 \pm 0.58$ fghi & $11.00 \pm 0.58 \mathrm{efgh}$ \\
\hline & Salmonella $\mathrm{sp}$ & $12.67 \pm 0.33 \mathrm{cde}$ & $12.33 \pm 0.33$ defgh & $11.67 \pm 0.33$ bcdef & $10.67 \pm 0.33 \mathrm{defg}$ \\
\hline \multirow{5}{*}{$\begin{array}{l}\text { Root }+ \\
\text { leaf }\end{array}$} & Bacillus sp & $13.00 \pm 0.58 \mathrm{def}$ & $14.00 \pm 0.58 \mathrm{~h}$ & $12.33 \pm 0.58$ defgh & $12.33 \pm 0.33 \mathrm{~h}$ \\
\hline & S. aureus & $15.00 \pm 0.58 \mathrm{f}$ & $13.00 \pm 0.58 \mathrm{efgh}$ & $14.00 \pm 0.58 \mathrm{hi}$ & $10.00 \pm 0.58 \mathrm{cdef}$ \\
\hline & P. aeruginosa & $12.00 \pm 0.58 \mathrm{bcde}$ & $11.00 \pm 0.58 \mathrm{bcd}$ & $14.33 \pm 0.33 \mathrm{i}$ & $10.67 \pm 0.33 \mathrm{defg}$ \\
\hline & Proteus sp & $13.00 \pm 0.58 \mathrm{def}$ & $13.00 \pm 0.58 \mathrm{efgh}$ & $11.67 \pm 0.33$ bcdef & $11.67 \pm 0.33 \mathrm{gh}$ \\
\hline & Salmonella $\mathrm{sp}$ & $15.00 \pm 0.58 \mathrm{f}$ & $12.33 \pm 0.33$ defgh & $12.33 \pm 0.33$ defgh & $11.33 \pm 0.33 \mathrm{fgh}$ \\
\hline \multirow{5}{*}{$\begin{array}{l}\text { Stem } \\
+ \text { leaf }\end{array}$} & Bacillus sp & $12.67 \pm 1.45 \mathrm{cde}$ & $12.33 \pm 0.33$ defgh & $12.00 \pm 0.58 \mathrm{cdefg}$ & $11.67 \pm 1.20 \mathrm{gh}$ \\
\hline & S. aureus & $10.00 \pm 0.00 \mathrm{ab}$ & $12.00 \pm 0.00 \mathrm{cdefg}$ & $12.33 \pm 0.67 \mathrm{defgh}$ & $11.67 \pm 0.67 \mathrm{gh}$ \\
\hline & P. aeruginosa & $13.00 \pm 1.54 \mathrm{def}$ & $13.33 \pm 0.58 \mathrm{fgh}$ & $13.00 \pm 0.58 \mathrm{fghi}$ & $11.00 \pm 0.58 \mathrm{efgh}$ \\
\hline & Proteus $\mathrm{sp}$ & $14.00 \pm 0.58 \mathrm{ef}$ & $11.00 \pm 0.58 \mathrm{bcd}$ & $11.00 \pm 0.58 \mathrm{bcde}$ & $10.67 \pm 0.33 \mathrm{defg}$ \\
\hline & Salmonella $\mathrm{sp}$ & $11.00 \pm 0.58 \mathrm{abcd}$ & $12.00 \pm 0.58 \mathrm{cdefg}$ & 13.00 \pm 0.58 fghi & $14.00 \pm 0.58 \mathrm{i}$ \\
\hline \multirow{5}{*}{$\begin{array}{l}\text { Stem+ } \\
\text { leaf+ root }\end{array}$} & Bacillus sp & $12.00 \pm 0.58 \mathrm{bcde}$ & $12.00 \pm 0.58 \mathrm{cdefg}$ & $10.00 \pm 0.58 \mathrm{~b}$ & $10.00 \pm 0.58 \mathrm{cdef}$ \\
\hline & S. aureus & $13.00 \pm 0.58 \mathrm{def}$ & $12.00 \pm 0.58 \mathrm{cdefg}$ & $12.00 \pm 0.58 \mathrm{cdefg}$ & $11.67 \pm 0.33 \mathrm{gh}$ \\
\hline & P. aeruginosa & $10.00 \pm 0.58 \mathrm{ab}$ & $9.00 \pm 0.58 \mathrm{a}$ & $0.00 \pm 0.00 \mathrm{a}$ & $0.00 \pm 0.00 \mathrm{a}$ \\
\hline & Proteus $\mathrm{sp}$ & $13.00 \pm 0.58 \mathrm{def}$ & $12.00 \pm 0.58 \mathrm{cdefg}$ & $13.00 \pm 0.58$ fghi & $10.00 \pm 0.58 \mathrm{cdef}$ \\
\hline & Salmonella $\mathrm{sp}$ & $13.00 \pm 0.58 \mathrm{def}$ & $12.33 \pm 0.58$ defgh & $13.67 \pm 0.67 \mathrm{ghi}$ & $9.33 \pm 0.33 \mathrm{bcd}$ \\
\hline
\end{tabular}

Each value is expressed as mean \pm standard error $(n=3)$. Different letters $(a, b, c, d, e, f, g, h, i)$ in each column indicate significant differences at $P<0.05$ according to the Duncan Statistics

The synergistic potency results of the different plant tissues showed that the highest zones of inhibition of $14.00 \mathrm{~mm}$ (Salmonella $\mathrm{sp}), 12.33 \mathrm{~mm}$ (Bacillus sp), $11.00 \mathrm{~mm}$ (P. aeruginosa), $11.67 \mathrm{~mm}$ (Proteus sp) and $11.67 \mathrm{~mm}$ (S. aureus) were obtained from leaf + stem, root + leaf, stem + leaf, root + leaf and stem +leaf+ root and stem + leaf respectively. There were significant variations $(P<0.05)$ in the highest zone of inhibition that was achieved on each of the bacteria under study

The antibacterial potency of the extracts suggests the presence of bioactive ingredients. Epidi et al. (2016a) reported that A.boonei contain phytochemicals such as tannins, saponins, flavonoids, cardiac glycosides and alkaloids. Epidi et al. (2016b) reported that Vitex grandifolia contain phytochemicals such as tannins, saponins, flavonoids, cardiac glycosides and alkaloids. Some of these phytochemicals have the tendency to wade off pests including microorganisms. The variations in the antimicrobial potentials of the different tissues of the plants could also be due to differences in the bioactive constituents in the various tissues (Epidi et al., 2016a,b).

The zone of inhibition were in the order of ethanol> methanol $>$ hexane $>$ aqueous. This trend has been reported for individual plants i.e A. boonei (Epidi et al., 2016a) and V. grandifolia (Epidi et al., 2016b). This could be due to differences in polarity of the solvents (Izah, 2018) and their extraction 
potentials. Generally, the values reported in this study appears to be superior than the result of the individual plants as reported by Epidi et al. (2016a,b). This is contrary to the findings of Karmegam et al. (2008) that reported an improved result of the synergistic effects of Balantes aegyptiaca, Hyptis sauveolens, Lawsonia inermis, Leucasaspera,Lobelia nicotianaefolia and Phyllanthus madraspatana using ethanol and water as extraction solvent. This trend could be due to the metabolism and physiology of the test organisms. Generally studies have reported that $\mathrm{pH}$ of the medium, temperature, water activity, oxygen and nutrient availability, choice of solvent, source of the organisms, biochemistry, physiology, metabolism and adaptation strategies of the microbes, plant species, biochemistry, age and parts, concentration of the plant extract and period of extraction could influence the sensitivity of plant extracts (Izah et al., 2018a-d; Izah and Aseibai, 2018; Izah, 2018; Kigigha et al., 2018, 2016, 2015).

Some of the bacteria were resistant to some of the extracts. The trend in some extracts i.e. microbes being resistant to some solvents is in agreement with the report of Gahlaut and Chillar (2013), Epidi et al. $(2016 a, b)$. Generally, the ability of both plants to inhibit the growth of the microbes used in this study suggest that they can be used as broad spectrum antibiotics(Izah et al., 2018a-d; Izah and Aseibai, 2018; Izah, 2018; Kigigha et al., 2018, 2016, 2015; Epidi et al., 2016a,b).

\section{CONCLUSION}

This study found that the combination of $V$. grandifolia and A. boonei extracts gives zone of inhibition in the order of ethanol> methanol > hexane > aqueous. The combination of two or more tissues also gave superior results. On the overall, both plants have antibacterial activities against the various bacteria under study. Hence they can be used as broad spectrum antibiotics.

\section{ACKNOWLEDGMENT}

The authors to thank Prof. Elijah I. Ohimain of Niger Delta University, Nigeria for supervising the MSc project work of the lead author in which this paper was extracted from.

\section{REFERENCES}

[1] Adomi, P.O. and Umukoro, G.E. (2010). Antibacterial Activity of Aqueous and Ethanol Crude Extracts of the Root Barks of A. booneiand Preliminary Phytochemical Test of Morinda lucida. Journal of Medicinal Plants Research,4(8), 644-648.

[2] Akinloye, O.A., Oshilaja, R.T., Okelanfa, O.A., Akinloye, D.I. and Idowu, O.M.O. (2013).Hypoglyceamic Activity of A. booneiStem Bark Extract in Mice. Agriculture and Biology Journal of North America, 4(1), $1-5$.

[3] Azokou A, Koné MW, Koudou BG and Bi HFT. (2013). Larvicidal Potential of Some Plants from West Africa Against Culex quinquefasciatus (Say) and Anopheles gambiae Giles (Diptera: Culicidae). Journal of Vector Borne Diseases, 20(2):103-110.

[4] Benson HJ (2002) Microbiological Applications: Laboratory Manual in General Microbiology. Complete version, 5th edition. McGraw-Hill, New York.

[5] Cheesbrough M (2004). District Laboratory Practice in Tropical Countries. Low price Edition tissues 2. Cambridge press, England.

[6] Epidi JO, Izah SC, Ohimain EI (2016a). Antibacterial and synergistic efficacy of extracts of Alstonia boonei tissues. British Journal of Applied Science, 1(1): 21 - 26.

[7] Epidi JO, Izah SC, Ohimain EI, Epidi TT (2016b). Antibacterial and synergistic potency of tissues of Vitex grandifolia. Biotechnological Research, 2(2), 69-76.

[8] Epidi TT, Odili EO (2009). Biocidal Activity of Selected Plant Powders Against Tribolium castaneum Herbst in Stored Groundnut (Arachis hypogaea L). African Journal of Environmental Science and Technology, 3:1-5.

[9] Ere D, Pondei K, Inaibo Q and Orutugu L (2014). Phytochemicals and Antimicrobial activity of plant parts of Ageratum conyzoides extracted using different solvents. Journal of Chemical, Biological and Physical Sciences, 4(4): 3429-3434.

[10] Fatima N, Ahmad T, Khan SJ, Deeba F and Zaidi N (2011). Assessment of antibacterial activity of in vitro and in vivo grown garlic (Allium sativum L.). Pakistan Journal of Botany, 43(6): 3029-3033.

[11] Gahlaut A, Chhillar AK (2013). Evaluation of Antibacterial Potential of Plant Extracts using Resazurin based Microtiter Dilution Assay. International journal of pharmaceutical sciences, 5(2): 372-376.

[12] Ganapaty S, Vidyadhar KN (2005). Phytoconstituents and Biological Activities of Vitex: A review. Journal of Natural Remedies, 5:75-95. 
[13] Karmegam, N., Karuppusamy, S., Prakash, M., Jayakumar, M. and Rajasekar, K. (2008). Antibacterial potency and synergistic effect of certain plant extracts against food-borne diarrheagenic bacteria. International Journal of Biomedical and Pharmaceutical Sciences, 2(2), 88 - 93.

[14] Izah SC (2018). Some determinant factors of antimicrobial susceptibility pattern of plant extracts. Research and Review Insight,2(3): 1-4

[15] Izah SC, Aseibai ER (2018). Antibacterial and Synergistic activities of methanolic leaf extract of Lemon grass (Cymbopogon citratus) and rhizome of Ginger (Zingiber officinale) against Escherichia coli, Staphylococcus aureus and Bacillus species. ACTA Microbiology, 1(6): 26-30.

[16] Izah S.C., Uhunmwangho E.J., and Eledo B.O., 2018a, Medicinal potentials of Buchholzia coriacea (wonderful kola), Medicinal Plant Research, 8(5): 27-43

[17] Izah SC, Zige DV, Alagoa KJ, Uhunmwangho EJ, Iyamu AO (2018b). Antibacterial Efficacy of Aqueous Extract of Myristica fragrans (Common Nutmeg). EC Pharmacology and Toxicology 6(4): 291-295.

[18] Izah SC, Uhunmwangho EJ, Dunga KE, Kigigha LT (2018c) Synergy of methanolic leave and stem-back extract of Anacardium occidentale 1. (cashew) against some enteric and superficial bacteria pathogens. MOJ Toxicol. 4(3):209-211.

[19] Izah SC, Uhunmwangho E.J., Etim NG (2018d). Antibacterial and synergistic potency of methanolic leaf extracts of Vernonia amygdalina L. and Ocimum gratissimum L. Journal of Basic Pharmacology and Toxicology, 2(1):8-12

[20] Kigigha LT, Selekere RE, Izah SC (2018). Antibacterial and synergistic efficacy of acetone extracts of Garcinia kola (Bitter kola) and Buchholzia coriacea (Wonderful kola). Journal of Basic Pharmacology and Toxicology, 2(1):13-17.

[21] Kigigha LT, Biye SE, Izah SC (2016). Phytochemical and antibacterial activities of Musanga cecropioides tissues against Escherichia coli, Pseudomonas aeruginosa Staphylococcus aureus, Proteus and Bacillus species. International Journal of Applied Research and Technology, 5(1), 100 - 107.

[22] Kigigha LT, Izah SC, Ehizibue M (2015). Activities of Aframomum melegueta Seed Against Escherichia coli, S. aureus and Bacillus species. Point Journal of Botany and Microbiology Research, 1(2):23 - 29.

[23] Lemmens RHMJ (2008). Vitex grandifolia Gürke. In: Louppe, D., Oteng-Amoako, A.A. \& Brink, M. (Editors). Prota 7(1): Timbers/Bois d'œuvre 1. [CD-Rom]. PROTA, Wageningen, Netherlands. http://database.prota.org/PROTAhtml/Vitex\%20grandifolia_En.htm. Accessed October 3 ${ }^{\text {rd }}, 2015$.

[24] Minocheherhomji FP and Vyas BM (2014). Presence of alkaloids in medicinal plants and their importance in antimicrobial activities of some pathogenic microbial strains. Journal of Environmental Research and Development, 9(1): $144-150$.

[25] Momoh J,Longe AO and Campbell CA (2014).In vivo anti-plasmodial and in vitro antioxidant activity of ethanolic leaf extract of Alstonia boonie (Ewe ahun) and its effect on some biochemical parameters in Swiss albino mice infected with Plasmodium berghei NK 65. European Scientific Journal, 10(8): 68 - 82.

[26] Nyananyo, B.L. (2006). Plants from the Niger Delta. Published by Onyoma Research Publication.

[27] Onwusonye, J.C. and Uwakwe, A.A. (2014). The Antiplasmodial Activity of Methanol Root Bark Extract of Alstonia Boonei against Plasmodium Berghei Berghei Infection in Mice. International Journal of Science and Research, 3(7), 2199 - 2201.

[28] Opoku F and Akoto O (2015). Antimicrobial and Phytochemical Properties of Alstonia Boonei Extracts. Organic Chemistry Current Research, 4(1): http://dx.doi.org/10.4172/2161-0401.1000137.

[29] Owolabi MA, Abass MM, Emeka PM, Jaja SI, Nnoli M, Dosa BOS (2010). Biochemical and Histologic Changes in Rats after Prolonged Administration of the Crude Aqueous Extract of the Leaves of Vitex grandifolia. Pharmacognosy Research, 2(5):273-278.

[30] Rani A and Sharma A (2013). The Genus Vitex: A review. Pharmacgnosy Reviews, 7 (14): 188 -198.

Citation: Justice Oyindeinyefa Epidi \& Esther Benafegha Enaregha, " Synergistic Efficacy of Tissue Extracts of Alstonia boonei and Vitex grandifolia against Some Common Bacteria Pathogens", International Journal of Research Studies in Biosciences (IJRSB), vol. 7, no. 1, pp. 8-13, 2019. http://dx.doi.org/10.20431/2349-0365. 0701002

Copyright: (C) 2019 Authors. This is an open-access article distributed under the terms of the Creative Commons Attribution License, which permits unrestricted use, distribution, and reproduction in any medium, provided the original author and source are credited. 